\title{
Evaluasi Kinerja Simpang Empat Bersinyal Dengan Metode MKJI dan Sidra Intersection
}

\author{
Fatmawati* $^{1}$, Mohamad Isram M. Ain ${ }^{2}$ \\ ${ }^{1,2}$ Jurusan Teknik Sipil, Politeknik Negeri Balikpapan, Jalan Soekarno Hatta Km. 8 \\ E-mail: *fatmawati@poltekba.ac.id
}

Received 21 November 2020; Reviewed 26 January 2021; Accepted 26 March 2021

Journal Homepage: http://jurnal.borneo.ac.id/index.php/borneoengineering

\begin{abstract}
In the lastest years development growth along the road MT. Haryono is experiencing very rapid growth, starting from property development, shopping centers, to the proliferation of culinary businesses along the side of the road, this has resulted in the high attractiveness of vehicles to the area. On the road MT. Haryono there are many intersections, but long queues occur most often at MT. Haryono - Ruhui Rahayu, vehicles queuing at the traffic light have to go through 2 to 3 cycle times to pass the intersection. This study aims to evaluate the performance of the intersection in existing conditions using two methods is MKJI 1997 and the SIDRA Intersection Program.The results of the intersection performance evaluation using the MKJI method obtained the Los D value in the north approaching arm with a delay value of $39.4 \mathrm{sec} / \mathrm{pvu}$, the Los F value in the south and west approaching arms with a delay value of $99.2 \mathrm{sec} / \mathrm{pvu}$ and $152.9 \mathrm{sec} / \mathrm{pvu}$ respectively, and for the east approach the value of Los $E$ with a delay time of $57.7 \mathrm{sec} / \mathrm{pvu}$. Meanwhile, in the Sidra Intersection analysis, it was obtained that the Los $F$ value on all approaching arms with an average delay time at all intersections of 122 sec/vehicle. For the DS value in the MKJI value on the north approach arm is 1.36, the south approach is 1.21, the west approach is 0.91, and the eastern approach is 0.80 while the DS value based on Sidra Intersection is 1.2 .
\end{abstract}

Keywords: Performance; Intersection; Congestion; SIDRA

\begin{abstract}
Abstrak
Pada lima tahun terakhir pertumbuhan pembangunan di sepanjang ruas jalan MT. Haryono mengalami pertumbuhan yang sangat pesat, mulai dari pembangunan property (perumahan dan ruko), pusat perbelanjaan, hingga menjamurnya usaha kuliner di sepanjang sisi ruas jalan, hal ini menyebabkan tingginya tarikan kendaraan menuju daerah tersebut. Pada ruas jalan MT. Haryono terdapat banyak simpang, namun antrian panjang paling sering terjadi pada simpangan MT. Haryono - Ruhui Rahayu, kendaraan yang mengantri di traffic light rata-rata harus melewati 2 hingga 3 kali cycle time untuk dapat melewati persimpangan tersebut. Penelitian ini bertujuan untuk mengevaluasi kinerja simpang pada kondisi eksisting menggunakan dua metode yaitu MKJI 1997 dan Program SIDRA Intersection, mengetahui perbedaan kinerja dari kedua metode tersebut, hingga ke rekomendasi upaya perbaikan simpang. Hasil evaluasi kinerja simpang dengan metode MKJI diperoleh nilai LoS D pada lengan pendekat utara dengan nilai tundaan sebesar 39.4 det/smp, nilai LoS F pada lengan pendekat selatan dan barat dengan nilai tundaan masing 99.2 det/smp dan 152.9 det/smp, dan untuk pendekat timur nilai Los E dengan waktu tundaaan sebesar 57.7 det/smp. Sedangkan pada analisis Sidra Intersection diperoleh nilai LoS F pada semua lengan pendekat dengan waktu tundaan rata-rata pada semua simpang sebesar 122 det/kend. Untuk nilai DS pada metode MKJI pada lengan pendekat utara sebesar 1.36, pendekat selatan 1.21, pendekat barat 0.91, dan pendekat timur 0.80 sedangkan nilai DS berdasarkan Sidra Intersectioan adalah sebesar 1.2.
\end{abstract}

Kata kunci: Kinerja; Simpang; Kemacetan; SIDRA 


\section{Pendahuluan}

Pertumbuhan kendaraan bermotor semakin meningkat dari tahun ke tahun yang tidak dibarengi dengan peningkatan fasilitas prasarana transportasi sehingga menyebabkan timbulnya kemacetan karena jumlah kendaraan yang semakin bertambah tidak dibarengi dengan peningkatan kapasitas jalan. Permasalahan transportasi di Kota Balikpapan mulai tampak pada beberapa titik yang mulai mengalami kemacetan, baik itu pada simpang maupun pada ruas jalan sehingga hal ini dapat memberikan dampak pada ruas jalan sekitarnya. Salah satu titik kemacetan yang menjadi perhatian pada penelitian ini adalah simpang empat bersinyal Jalan MT Haryono. Pada lima tahun terakhir tingkat pembangunan di sepanjang ruas jalan MT. Haryono mengalami pertumbuhan yang sangat pesat, mulai dari pembangunan property (perumahan dan ruko), pusat perbelanjaan, hingga menjamurnya usaha kuliner di sepanjang sisi ruas jalan, hal ini menyebabkan tingginya tarikan kendaraan menuju daerah tersebut. Meski demikian, kinerja ruas jalan di sepanjang ruas jalan MT. Haryono masih relatif normal, berbeda halnya dengan kinerja simpang pada beberapa titik simpang. Pada ruas jalan MT. Haryono terdapat banyak simpang, namun salah satu simpang yang menjadi perhatian karena seringkali mengalami antrian kendaraan yang cukup panjang hingga menyebabkan kemacetan yakni simpang empat MT. Haryono - Ruhui Rahayu. Berdasarkan hasil pengamatan, kendaraan yang mengantri di traffic light umumnya harus melewati 2 hingga 3 fase lampu merah untuk dapat melewati persimpangan tersebut sehingga menyebabkan terjadinya tundaan (delay) yang cukup lama. Maka dari itu perlu dilakukan evaluasi kinerja simpang agar dapat diketahui nilai tundaan yang terjadi sehingga nantinya dapat ditentukan langkah tepat yang perlu dilakukan untuk memperbaiki kinerja simpang tersebut.

Berkaitan dengan permasalahan yang sedang dikaji terdapat beberapa penelitian terdahulu terkait perbaikan kinerja simpang, dimana dari penelitian tersebut memberikan beberapa solusi di antaranya skenario pengaturan simpang dan perubahan geometric simpang. Menurut M. Zainul Arifin dkk (2017) menyatakan bahwa "Pada simpang yang tidak terkoordinasi dengan baik terdapat dua skenario pengaturan simpang yaitu pengaturan ulang sinyal dan perubahan geometrik simpang dengan teknik trial and error waktu siklus". Sedangkan Dwiyono dkk (2016) juga mengemukakan bahwa "upaya perbaikan simpang juga dapat dilakukan dengan perubahan geometric pada simpang namun hal tersebut tidak dapat menjamin peluang antrian menjadi lebih baik".

Berdasarkan uraian permasalahan di atas maka perlu adanya evaluasi kinerja simpang pada simpang MT. Haryono - Ruhui Rahayu sehingga dapat diketahui bagaimana status tingkat pelayanan eksisting pada simpang tersebut. Dalam proses analisis evaluasi kinerja simpang menggunakan metode MKJI dan program SIDRA intersection. Penelitian sebelumnya yang membandingkan dua metode ini telah dilakukan oleh Julia Astuti dkk (2013) "menyatakan bahwa pada setiap variasi waktu siklus nilai DS pada aaSidra cenderung mendekati 0,8 sedangkan pada MJKI 1997 semakin besar variasi waktu siklus maka semakin besar pula nilai DS". Penelitian serupa juga telah dilakukan oleh Arnetha Sari Raintung (2012) "mengemukakan bahwa dari hasil perhitungan derajat kejenuhan dengan menggunakan MKJI 1997 dan aaSIDRA diperoleh hasil yang sama yakni nilai DS di atas batas normal (melampaui jenuh)"

Hasil dari evaluasi simpang nantinya akan digunakan sebagai pertimbangan dalam membuat rekomendasi sebagai upaya perbaikan kinerja simpang, baik melalui rekayasa maupun manajemen lalu lintas. Sebagaimana Dwijoko dkk (2016) menyatakan bahwa "Kinerja simpang akan menjadi lebih baik dengan dilakukannya manajemen lalu lintas berdasarkan skenario arus yang diterapkan pada kapasitas simpang". Penelitian lain yang menerapkan manajemen lalu lintas sebagai solusi dalam perbaikan kinerja simpang telah dilakukan oleh Rama Dwi Aryandi dkk (2017) yang 
menyatakan bahwa "salah satu upaya memperbaiki derajat kejenuhan (DS) simpang yang terlampau jenuh adalah dengan melakukan peniadaan hambatan samping, pelarangan belok kiri langsung dan optimalisasi traffic light".

\section{Tinjauan Pustaka}

\subsection{Persimpangan}

Menurut Ofyar Z. Tamin (2008) persimpangan juga dapat didefenisikan sebagai suatu ruang/tempat pertemuan antara 2 atau lebih ruas jalan yang bertemu atau bersilangan;bervariasi dari persimpangan yang sangat sederhana yang terdiri dari ruang/tempat pertemuan antara 2 (dua) ruas jalan sampai dengan persimpangan yang sangat kompleks berupa ruang/tempat pertemuan beberapa (>2) ruas jalan. Persimpangan dapat didefinisikan sebagai daerah umum dimana dua jalan atau lebih bergabung atau bersimpangan, termasuk jalan dan fasilitas tepi jalan untuk pergerakan lalu lintas di dalamnya. Karakteristik simpang sangat mempengaruhi bagaimana jenis pengaturan lalu lintas yang sesuai untuk suatu simpang, adapun karakteristik simpang yang dimaksud yaitu:

1) Volume dan kapasitas yang secara langsung mempengaruhi hambatan

2) Desain geometrik dan kebebasan pandang

3) Kecelakaan dan keselamatan jalan, kecepatan, lampu jalan

4) Parkir, akses, dan pembangunan yang sifatnya umum

5) Pejalan kaki

6) Jarak antar persimpangan

\subsection{Manual Kapasitas Jalan Indonesia 1997 (MKJI 1997)}

Manurut MKJI 1997 "Simpang bersinyal adalah suatu persimpangan yang terdiri dari beberapa lengan dan dilengkapi dengan pengaturan sinyal lampu lalu lintas"

Ukuran kinerja simpang dapat ditentukan berdasarkan tundaan/ hambatan di persimpangan. Tundaan (D) pada suatu simpang dapat berupa tundaan lalu lintas (DT) karena interaksi lalulintas dengan gerakan lainnya pada suatu simpang dan tundaan geometri (DG) karena perlambatan dan percepatan saat membelok pada suatu simpang dan atau terhenti karena lampu merah.

\subsubsection{Geometrik dan Kondisi Lingkungan}

Perhitungan geometric dikerjakan secara terpisah untuk setiap pendekat, berikut parameter geometrik pada simpang bersinyal.

1) Pada 1 lengan simpang dapat terdiri lebih dari 1 pendekat, yaitu dipisahkan menjadi dua atau lebih sub pendekat. Hal ini terjadi jika gerakan belok-kanan dan/atau belok - kiri mendapat sinyal hijau pada fase yang berlainnan dengan lalu lintas yang lurus, atau jika dipisahkan secara fisik dengan pulau - pulau lalu-lintas dalam pendekat

2) Untuk masing - masing pendekat atau sub-pendekat lebar efektif (We) ditetapkan dengan mempertimbangan denah dari bagian masuk dan ke luar suatu simpang dan distribusi dari gerakan - gerakan membelok.

3) Tipe lingkungan jalan dibedakan menjadi 3 yaitu komersial, permukiman dan akses terbatas

4) Tingkat hambatan samping, dibagi menjadi 2 yaitu:

a. Tinggi $=$ Besar arus berangkat pada tempat masuk dan ke luar berkurang oleh karena aktivitas disamping jalan pada pendekat seperti angkutan umum berhenti, pejalan kaki berjalan sepanjang atau melintas pendekat, keluar - masuk halaman disamping jalan.

b. Rendah = besar arus berangkat pada tempat masuk dan keluar tidak berkurang oleh hambatan samping dari jenis-jenis yang disebut di atas.

5) Median, masukkan jika terdapat median pada bagian kanan dari garis henti dalam pendekat.

6) Kelandaian, masukkan kelandaian dalam $\%($ naik $=+\%$; turun $=-\%$ ) 
7) Belok kiri langsung, masukkan jika belok kiri langsung (LTOR) diijinkan pada pendekat tersebut. Belok kiri langsung $\left(\mathrm{W}_{\mathrm{LTOR}}\right)$ dalam perhitungan sangat berpengaruh pada We. Apabila $\mathrm{W}_{\mathrm{LTOR}}<2$ meter maka $\mathrm{We}=\mathrm{W}_{\mathrm{A}}$, jika $\mathrm{W}_{\mathrm{LTOR}} \geq 2$ meter maka $\mathrm{We}=\mathrm{W}_{\mathrm{A}}-\mathrm{W}_{\mathrm{LTOR}}$.

8) Jarak ke kendaraan parkir, masukkan jarak normal antara garis-henti dan kendaraan pertama yang diparkir di sebelah hulu pendekat, untuk kondisi yang dipelajari.

9) Lebar pendekat. Masukkan, dari sketsa, lebar (ketelitian sampai sepersepuluh meter terdekat) bagian yang diperkeras dari masing masing pendekat (hulu dari titik belok untuk LTOR), belok kiri langsung, tempat masuk dan tempat keluar (bagian tersempit setelah melewati jalan melintang).

\subsubsection{Indikator Kinerja Simpang}

1) Arus lalu lintas $(\mathrm{Q})$ untuk setiap arus kendaraan ringan, kendaraan berat, dan sepeda motor (QLV, QHV, dan QMC) dikonversi dari kendaran per jam menjadi satuan mobil penumpang (smp) per jam dengan menggunakan ekivalen kendaraan penumpang (emp) untuk masingmasing pendekat terlindung dan terlawan.

Tabel 1. Nilai emp Kendaraan

\begin{tabular}{lll}
\hline Tipe Kendaraan & emp & \\
\cline { 2 - 3 } & Pendekat & Pendekat \\
\cline { 2 - 3 } & Terlindung & Terlawan \\
\hline LV & 1,0 & 1,0 \\
HV & 1,3 & 1,3 \\
MC & 0,2 & 0,4 \\
\hline
\end{tabular}

Sumber: MKJI, 1997

Arus lalu lintas kendaraan diperoleh melalui survey lalu lintas, dihitung untuk masing-masing pendekat rasio kendaraan belok kiri $\mathrm{P}_{\mathrm{LT}}$, dan rasio belok kanan $\mathrm{P}_{\mathrm{RT}}$. Untuk menghitung arus dapat menggunakan rumus berikut:

$$
\mathrm{Q}=\mathrm{Q}_{\mathrm{LV}}+\mathrm{Q}_{\mathrm{HV}} \mathrm{x} \mathrm{emp}_{\mathrm{HV}}+\mathrm{Q}_{\mathrm{MC}} \mathrm{x} \mathrm{emp}_{\mathrm{MC}}
$$

Rasio belok kiri dan rasio belok kanan:

$$
\mathrm{P}_{\mathrm{LT}}=\frac{Q_{L T}}{Q_{T O T}} \quad \mathrm{P}_{\mathrm{RT}}=\frac{Q_{R T}}{Q_{T O T}}
$$

Rasio kendaraan tak bermotor: $\quad \mathrm{P}_{\mathrm{UM}}=\frac{\mathrm{Q}_{\mathrm{UM}}}{\mathrm{Q}_{\mathrm{MV}}}$

2) Waktu Antar Hijau dan Waktu Hilang

a. Tentukan waktu merah yang diperlukan untuk pengosongan pada setiap akhir fase dan hasil waktu antara hijau (IG) per fase.

b. Tentukan waktu hilang (LTI) sebagai jumlah dari waktu antar hijau per siklus.

c. Waktu hilang (LTI) didefenisikan sebagai jumlah semua periode antar hijau dalam siklus yang lengkap (detik).

d. Untuk analisa perancangan, waktu hijau berikut (kuning + merah semua) dapat dianggap sebagai nilai normal seperti pada tabel 2 berikut. 
Tabel 2. Faktor Penyesuaian Lebar Simpang

\begin{tabular}{lll}
\hline Ukuran simpang & Lebar jalan rata-rata & Nilai normal waktu antar - hijau \\
\hline Kecil & $6-9 \mathrm{~m}$ & $4 \mathrm{detik} /$ fase \\
Sedang & $10-14 \mathrm{~m}$ & $5 \mathrm{detik} /$ fase \\
Besar & $\geq 15 \mathrm{~m}$ & $\geq 6 \mathrm{detik} /$ fase \\
\hline
\end{tabular}

Sumber: MKJI, 1997

3) Tipe Pendekat

Pendekat didefenisikan sebagai daerah dari suatu lengan persimpangan jalan untuk kendaraan mengantri sebelum keluar melewati garis henti (bila gerakan lalu-lintas ke kiri atau ke kanan dipisahkan dengan pulau lalu-lintas, sebuah lengan persimpangan jalan dapat mempunyai dua pendekat).

4) Lebar efektif (We) adalah lebar dari bagian pendekat yang diperkeras, yang digunakan dalam perhitungan kapasitas (yaitu dengan pertimbangan terhadap WA, WMASUK, dan WKELUAR dan gerakan lalu-lintas membelok).

5) Arus Jenuh Dasar $\left(\mathrm{S}_{0}\right)$

Arus jenuh dasar adalah besarnya keberangkatan antrian di dalam suatu pendekat selama kondisi ideal. Untuk pendekat tipe P (arus terlindung) digunakan rumus berikut:

$$
\mathrm{S}_{0}=600 \times \mathrm{We}
$$

Arus jenuh yang disesuaikan untuk simpang bersinyal dapat dihitung dengan rumus berikut:

$$
S=S_{0} \times F_{C S} \times F_{S F} \times F_{G} \times F p \times F_{L T} \times F_{R T}
$$

6) Waktu Siklus dan Waktu Hijau

Waktu siklus sebelum penyesuaian, gunakan rumus berikut:

Waktu Hijau

$$
\text { cua }=(1,5 \times \text { LTI }+5) /(1-\text { IFR })
$$

dimana:

$$
\text { gi }=(\text { cua }- \text { LTI }) \times \text { PRi }
$$

$$
\begin{array}{ll}
\text { cua } & \text { = waktu siklus sebelum penyesuaiansinyal (det) } \\
\text { gi } & =\text { tampilan waktuhijau pada fasei(det) } \\
\text { LTI } & =\text { waktu hilang total per siklus (det) } \\
\text { IFR } & =\text { rasio arus simpang } \sum \text { (FRcrit) } \\
\text { PRi } & =\text { rasio faseFrcrit } / \sum \text { Frcrit }
\end{array}
$$

Waktu siklus yang disesuaikan (c) berdasar pada waktu hijau yang diperoleh dan telah dibulatkan dan waktu hilang (LTI), gunakan rumus berikut:

$$
\mathrm{C}=\sum \mathrm{g}+\mathrm{LTI}
$$

7) Kapasitas (C) dan Derajat Kejenuhan (DS)

Perhitungan kapasitas masing - masing pendekat, gunakan rumus berikut:

$$
\mathrm{C}=\mathrm{S} \times \mathrm{g} / \mathrm{c}
$$

Perhitungan derajat kejenuhan masing - masing pendekat, gunakan rumus berikut:

$$
\mathrm{DS}=\mathrm{Q} / \mathrm{C}
$$

8) Jumlah Kendaraan Antri. Jumlah kendaraan antri (smp) terdiri dari jumlah kendaraan yang tersisa dari fase hijau sebelumnya (NQ1) dan jumlah kendaraan yang datang selama fase merah (NQ2). NQ1 dihitung dengan menggunakan rumus berikut:

$$
\mathrm{NQ}_{1}=0,25 \times \mathrm{C} \times(\mathrm{DS}-1)+\sqrt{(D S-1)^{2}+\frac{8 x(D S-0,5)}{C}}
$$

Jika DS $\leq 0,5$ maka, NQ1 $=0$ 
Dimana:

DS = Derajat jenuh

$\mathrm{C} \quad=\operatorname{kapasitas}(\mathrm{smp} / \mathrm{jam})=$ arus jenuh $\mathrm{x}$ rasio hijau $(\mathrm{S} \times \mathrm{GR})$

GR = Rasio hijau

Jumlah kendaraan yang datang selama fase merah (NQ2) dihitung dengan rumus berikut:

$$
\mathrm{NQ}_{2}=\mathrm{c} \times \frac{1-G R}{1-G R \times D S} \times \frac{Q}{3600}
$$

Dimana: NQ2 = jumlah smp yang datang selama fase merah

$$
\begin{array}{ll}
\mathrm{DS} & =\text { derajat kejenuhan } \\
\mathrm{GR} & =\text { rasio hijau } \\
\mathrm{C} & =\text { waktu siklus }(\mathrm{det}) \\
\mathrm{Q} \text { masuk } & =\text { arus lalu lintas pada tempat masuk diluar LTOR (smp/jam) }
\end{array}
$$

10) Panjang antrian (QL) (m) dihitung dengan rumus berikut:

$$
\mathrm{QL}=\frac{N Q \cdot \max \times 20}{W \cdot \operatorname{masuk}}
$$

11) Angka Henti dan Jumlah Kendaraan Terhenti

Angka henti (NS) masing - masing pendekat didefenisikan sebagai jumlah rata-rata berhenti per smp (termasuk berhenti berulang dalam antrian). Angka henti seluruh simpang dapat dihitung dengan membagi jumlah kendaraan terhenti pada seluruh pendekatarussimpang totalQ (kend/jam).

$$
\mathrm{NS}_{\mathrm{tot}}=\frac{\Sigma N S V}{Q \cdot t o t}
$$

12) Tundaan

Tundaan lalu-lintas rata-rata setiap pendekat (DT) akibat pengaruh timbal balik dengan gerakan kendaraan lainnya pada simpang. Untuk menghitung tundaan pada setiap pendekat, gunakan rumus sebagai berikut:

$$
\mathrm{DT}=C \times A+\frac{N Q 1 \times 3600}{C} \text { dimana } \mathrm{A}=\frac{0,5 \times(1-G R)^{2}}{(1-G R \times D S)}
$$

- Untuk menghitung konstanta A, gunakan grafik berikut :

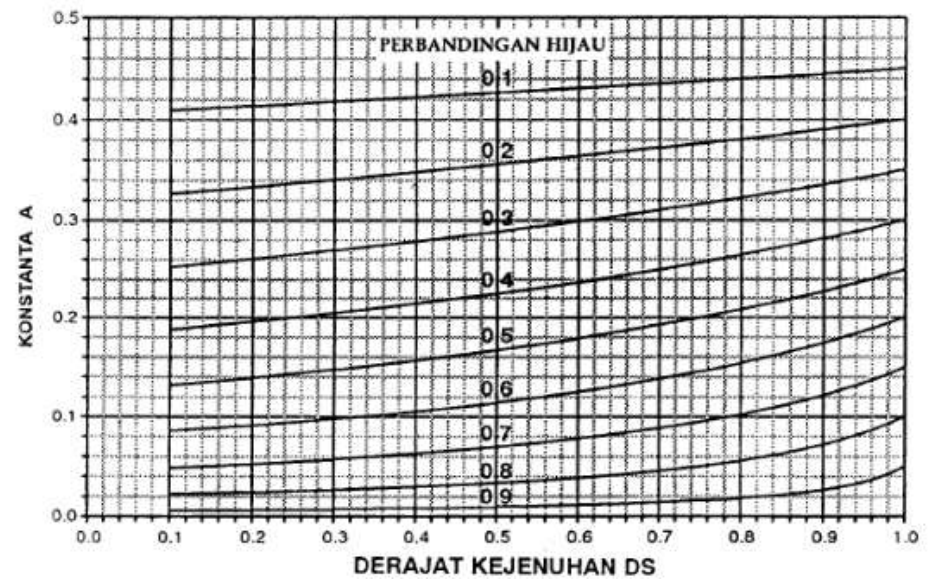

Gambar 1. Grafik Penyesuaian Nilai A (sumber MKJI) 
Tundaan geometri rata-rata masing-masing pendekat (DG) akibat pertambahan dan percepatan ketika menunggu giliran pada suatu simpang dan atau ketika diberhentikan oleh lampu merah, digunakan rumus berikut:

$$
\mathrm{DGj}=\left(1-\mathrm{P}_{\mathrm{SV}}\right) \times \mathrm{P}_{\mathrm{T}} \times 6+\left(\mathrm{P}_{\mathrm{SV}} \times 4\right)
$$

dimana:

DG1 = tundaan geometri rata-rata untuk pendekat $\mathrm{j}(\operatorname{det} / \mathrm{smp})$

$\mathrm{P}_{\mathrm{SV}} \quad=$ rasio kendaraan terhenti pada pendekat $=$ Min $(\mathrm{NS}, 1)$

$\mathrm{P}_{\mathrm{T}} \quad=$ rasio kendaraan berbelok pada pendekat

Tundaan rata-rata untuk seluruh simpang (D1) dihitung dengan membagi jumlah nilai tundaan dengan arus total $\left(\mathrm{Q}_{\text {тот }}\right)$ dalam smp/jam.

$$
\mathrm{QL}=\frac{N Q \cdot \max \times 20}{\text { Q.Masuk }}
$$

\subsubsection{Tingkat Pelayanan Simpang}

Tingkat pelayanan simpang adalah ukuran kondisi lalu lintas yang dapat diterima oleh pengemudi kendaraan bermotor. Tingkat Pelayanan umumnya digunakan sebagai ukuran dari pengaruh yang membatasi akibat peningkatan volume lalu lintas setiap ruas jalan yang dapat digolongkan pada tingkat tertentu yaitu antara A sampai F berdasarkan hasil penelitian Iqbal dkk (2017).

\begin{tabular}{|c|c|}
\hline Tundaan per Kendaraan (det/smp) & Tingkat Pelayanan \\
\hline$<5$ & A \\
\hline $5,1-15$ & B \\
\hline $15,1-25$ & $\mathrm{C}$ \\
\hline $25,1-40$ & D \\
\hline $40,1-60$ & $\mathrm{E}$ \\
\hline$>60$ & F \\
\hline
\end{tabular}

Tabel 3. Kriteria Tingkat Pelayanan Untuk Simpang Bersinyal

\subsection{Sidra Intersection}

Sidra Intersection adalah singkatan dari Signalized and unsignalised Intersection Design ResearchAid. Sidra Intersection sebelumnya disebut SIDRA dan AASIDRA adalah suatu perangkat lunak yang digunakan untuk menganalisa kapasitas, tingkat layanan dan kinerja lalu lintas eksisting atau desain pada persimpangan sebidang (junction)

Prinsip pengolahan data pada software Sidra menggunakan model analisis lalu lintas secara detail berupa lane by lane analyze yang merupakan suatu metode analisis kinerja dengan memperhatikan masing-masing lajur dan digabungkan dengan metode perkiraan untuk memberikan perkiraan kapasitas dan tampilan kinerja lainnya. Sedangkan pada metode MKJI 1997 analisis kinerja dilakukan per lengan simpang. Perbedaan ini juga telah dikemukakan oleh John H Fransk dkk (2018) bahwa perbedaan mendasar antara metode MKJI dan Sidra Intersection adalah pada pengolahan data Sidra analisis dilakukan dengan metode Weaving Section atau analisis perjalinan. Program SIDRA menggunakan model lalu lintas rinci analitis digabungkan dengan metode pendekatan iterasi untuk memberikan perkiraan kapasitas dan statistik kinerja (tundaan, panjang antrian, level of service, dll). 


\section{Metode Penelitian}

\subsection{Lokasi Penelitian}

Lokasi penelitian dilaksanakan di Kota Balikpapan dimana objek penelitian difokuskan pada simpang empat bersinyal Jalan MT. Haryono - Jalan Ruhui Rahayu. Pada Gambar 2 berikut menunjukkan peta lokasi penelitian, dimana tanda lingkaran merah merupakan titik simpang yang diamati.

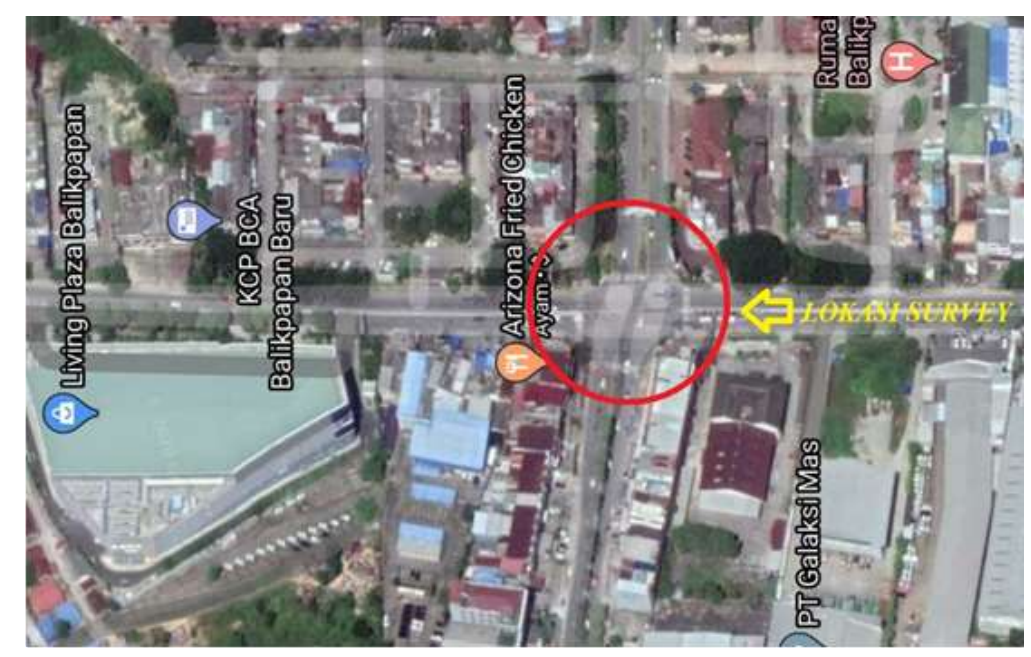

Gambar 2. Peta lokasi Penelitian (Sumber: google map)

\subsection{Metode Pengumpulan Data}

Metode pengumpulan data yang dilakukan dalam penelitian ini berupa survey geometrik jalan dan survey lalu lintas. Pada survey geometrik jalan dilakukan pengamatan dan pengukuran terhadap semua perangkat jalan yang ada pada simpang yakni pengamatan peruntukan lahan, penggunaan parkir badan jalan, kepatuhan pengendara, selanjutnya dilakukan pengukuran lebar jalan, bahu jalan, median, trotoar, fase sinyal, panjang antrian kendaraan, dan jumlah antrian kendaraan disemua lengan pendekat. Pada survey lalu lintas (traffic counting/tc) dilakukan pengamatan dan perhitungan volume kendaraan yang melintas di semua kaki simpang, hal ini untuk mengetahui volume lalu lintas harian rata-rata kendaraan yang melalui simpang yang diamati. Waktu pengambilan data ditetapkan pada hari hari kerja (senin dan jumat) dan hari libur (minggu).

\subsection{Tahapan Penelitian}

Penelitian dilakukan pada satu titik simpang dengan tahapan-tahapan penelitian sebagai berikut:

1) Identifikasi Masalah, merupakan pengamatan awal terhadap permasalahan yang terjadi pada pada ruas Jalan MT. Haryono, dimana pada kawasan tersebut sering terjadi kemacetan yang diakibatkan oleh volume kendaraan yang semakin meningkat terutama pada jam sibuk, cycle time kurang optimal sehingga menyebabkan antrian panjang.

2) Inventarisasi kebutuhan data dilakukan untuk merumuskan data-data yang dibutuhkan dalam suatu analisa data, baik data sekunder maupun data primer.

3) Pengumpulan data primer dan sekunder, dimana data primer diperoleh dengan survey lapangan berupa survey lalu lintas, kondisi geometrik jalan, dan kondisi lingkungan. Sedangkan data sekunder berupa data volume lalu lintas harian rata-rata yang didapatkan 
dari Dinas Perhubungan Kota Balikpapan sebagai data pembanding volume lalu lintas yang dilakukan secara langsung.

4) Kompilasi data yang telah diperoleh dan kemudian dilakukan analisis dengan metode MKJI 1997 dan Program SiDRA

5) Analisis dan pembahasan. Bagaimana hasil yang diperoleh setelah dilakukan analisis data. Bagaimana perbandingan hasil evaluasi kinerja simpang berdasarkan metode MKJI dan SIDRA Intersection, apakah masih memenuhi ambang normal waktu tundaan atau tidak (D>60 det/smp). Jika tundaan berada di angka > $60 \mathrm{det} / \mathrm{smp}$ atau berada pada tingkat pelayanan F maka perlu dilakukan upaya pernaikan kinerja simpang.

\subsection{Proses Pengolahan Data}

Proses pengolahan data dilakukan dengan tahapan sebagai berikut:

1) Setelah data terkumpul maka proses pengolahan data dimulai dengan melakukan rekapitulasi data volume hingga dihasilkan volume kendaraan pada jam puncak pada masing-masing pendekat.

2) Selanjutnya dilakukan olah data berdasarkan form SIG I sampai dengan SIG 5 untuk analisis metode MKJI 1997, dimana dari hasil olah data diperoleh nilai arus lalu lintas, kapasitas, derajat kejenuhan, jumlah kendaraan henti dan lama tundaan lalu lintas pada setiap lengan pendekat (lengan simpang).

3) Melakukan input data simpang pada software Sidra, dimana pada saat pertama kali mebuka program sidra terlebih dahulu memilih option signal at grade intersection, selanjutnya melakukan input data pada kolom site input berdasarkan urutan data yang telah ditentukan yakni mulai dari data intersection, movement definitions, lane geometry, lane movements, pedestrian, volumes, priporities, vehicle movement, phasing \& timing, dan parameter setting. Setelah melakukan input data maka program akan melakukan running dan hasilnya akan ditampilkan dalam kolom site output.

4) Selanjutnya dilakukan interpretasi terhadap hasil evaluasi metode MKJI 1997 dan program Sidra Intersection.

\section{Hasil dan Pembahasan}

\subsection{Volume Simpang}

Pengambilan data arus lalu lintas dilaksanakan sebanyak 2 (dua) kali, yaitu pada hari Minggu mewakili hari libur (weekend) dan hari Senin mewakili hari kerja (weekday). Pengamatan ini dilakukan untuk mengetahui arus volume lalu lintas masing-masing kendaraan yang melintasi simpang MT. Haryono - Balikpapan Baru. Dari hasil olah data survey volume lalu lintas diperoleh rekapitulasi volume lalu lintas pada simpang Jalan MT. Haryono - Jalan Ruhui Rahayu seperti terlihat pada Tabel 4 dan Tabel 5.

Tabel 4. Data Lalu Lintas Pada Hari Libur (Minggu)

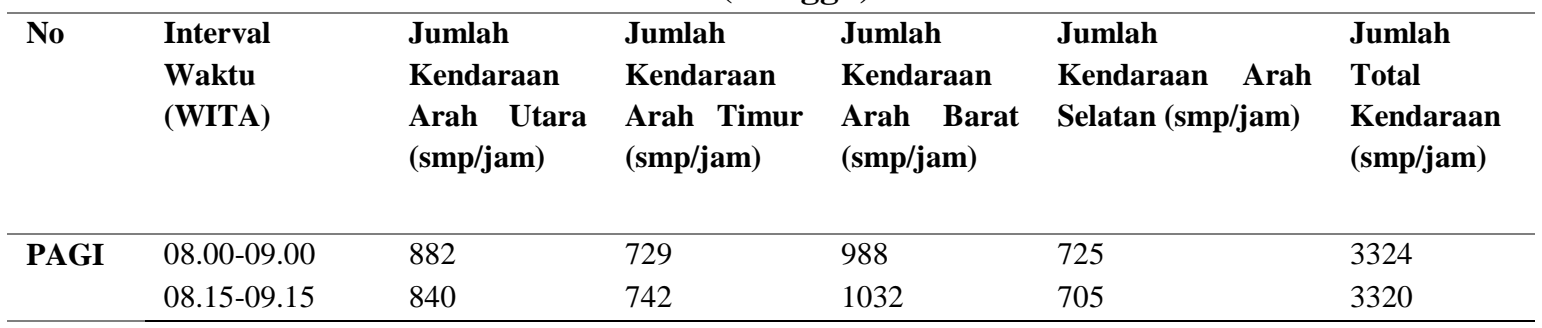




\begin{tabular}{lllllll}
\hline & $08.30-09.30$ & 860 & 731 & 1044 & 737 & 3372 \\
& $08.45-09.45$ & 839 & 754 & 1028 & 736 & 3356 \\
& $09.00-10.00$ & 841 & 790 & 1014 & 759 & $\mathbf{3 4 0 5}$ \\
\hline SORE & $16.00-17.00$ & 628 & 656 & 880 & 695 & 2858 \\
& $16.15-17.15$ & 623 & 684 & 877 & 683 & 2867 \\
& $16.30-17.30$ & 632 & 684 & 877 & 690 & 2883 \\
& $16.45-17.45$ & 572 & 706 & 865 & 673 & 2816 \\
& 17.00 .18 .00 & 569 & 716 & 856 & 685 & 2826 \\
\hline
\end{tabular}

Sumber : Analisis Data

Tabel 5. Data Lalu Lintas Pada Hari Kerja (Senin)

\begin{tabular}{ccccccc}
\hline No & $\begin{array}{c}\text { Interval } \\
\text { Waktu } \\
\text { (WITA) }\end{array}$ & $\begin{array}{c}\text { Jumlah } \\
\text { Kendaraan } \\
\text { Arah Utara } \\
\text { (smp/jam) }\end{array}$ & $\begin{array}{c}\text { Jumlah } \\
\text { Kendaraan } \\
\text { Arah Timur } \\
\text { (smp/jam) }\end{array}$ & $\begin{array}{c}\text { Jumlah } \\
\text { Kendaraan } \\
\text { Arah Barat } \\
\text { (smp/jam) }\end{array}$ & $\begin{array}{c}\text { Jumlah } \\
\text { Kendaraan } \\
\text { Arah Selatan } \\
\text { (smp/jam) }\end{array}$ & $\begin{array}{c}\text { Jumlah Total } \\
\text { Kendaraan } \\
\text { (smp/jam) }\end{array}$ \\
\hline PAGI & $08.00-09.00$ & 749 & 857 & 899 & 829 & 3333 \\
& $08.15-09.15$ & 793 & 884 & 868 & 843 & 3389 \\
& $08.30-09.30$ & 837 & 870 & 892 & 861 & 3459 \\
& $08.45-09.45$ & 837 & 844 & 889 & 878 & 3448 \\
& $09.00-10.00$ & 890 & 838 & 878 & 870 & $\mathbf{3 4 7 5}$ \\
\hline SORE & $16.00-17.00$ & 601 & 792 & 939 & 747 & 3079 \\
& $16.15-17.15$ & 596 & 787 & 949 & 741 & 3073 \\
& $16.30-17.30$ & 612 & 782 & 961 & 714 & 3069 \\
& $16.45-17.45$ & 638 & 796 & 926 & 703 & 3063 \\
\hline
\end{tabular}

Sumber : Analisis Data

\subsection{Geometrik Jalan dan Kondisi Lingkungan}

Kota Balikpapan memiliki jumlah penduduk sebesar 655.178 jiwa dengan ukuran kota sebesar $508,39 \mathrm{Km}^{2}$. Survey tata guna lahan dilakukan untuk mengetahui type lingkungan jalan dan kondisi hambatan samping pada tiap - tiap lengan simpang. Adapun data geometrik dan desain geometrik simpang dapat di lihat pada tabel 6 dan gambar 3 .

Tabel 6. Data Geometrik dan Kondisi Lingkungan Pada Simpang MT. Haryono - Ruhui Rahayu

\begin{tabular}{lcccr}
\hline Kode Pendekat & Utara & Selatan & \multicolumn{1}{c}{ Barat } & Timur \\
\hline Tipe lingkungan jalan & COM & COM & COM & COM \\
Median & Ya & Ya & Ya & Ya \\
LTOR & Ya & Ya & Ya & Ya \\
Lebar pendekat (WA) m & 9,85 & 9,6 & 11,6 & 7,48 \\
Lebar pendekat masuk (Wmasuk) m & 6,5 & 6,7 & 7,80 & 4,95 \\
Lebar pendekat LTOR (WLTOR) m & 3,35 & 2,9 & 4 & 2.55 \\
Lebar pendekat keluar (Wkeluar) m & 10,35 & 6,7 & 4,95 & 8,2
\end{tabular}

\section{Sumber: Data survey}

\subsection{Rasio Berbelok}

Berdasarkan analisis pada Form SIG II diperoleh rekapitulasi hasil arus lalu lintas dan hasil rasio berbelok pada tiap-tiap lengan pendekat. Berdasarkan Ttabel 6 diketahui total volume kendaraan tertinggi berada pada lengan pendekat arah utara dengan total volume kendaraan sebesar 891 smp/jam yang terdiri atas $488 \mathrm{smp} / \mathrm{jam}$ ke arah lurus, $266 \mathrm{smp} / \mathrm{jam}$ arah belok kanan dan 137 smp/jam yang belok kiri langsung. Dari total volume tersebut diperoleh nilai rasio kendaraan belok 
kiri sebesar 0,15 dan rasio belok kanan sebesar 0,30. Data selengkapnya dapat di lihat pada Tabel 7 di bawah ini.

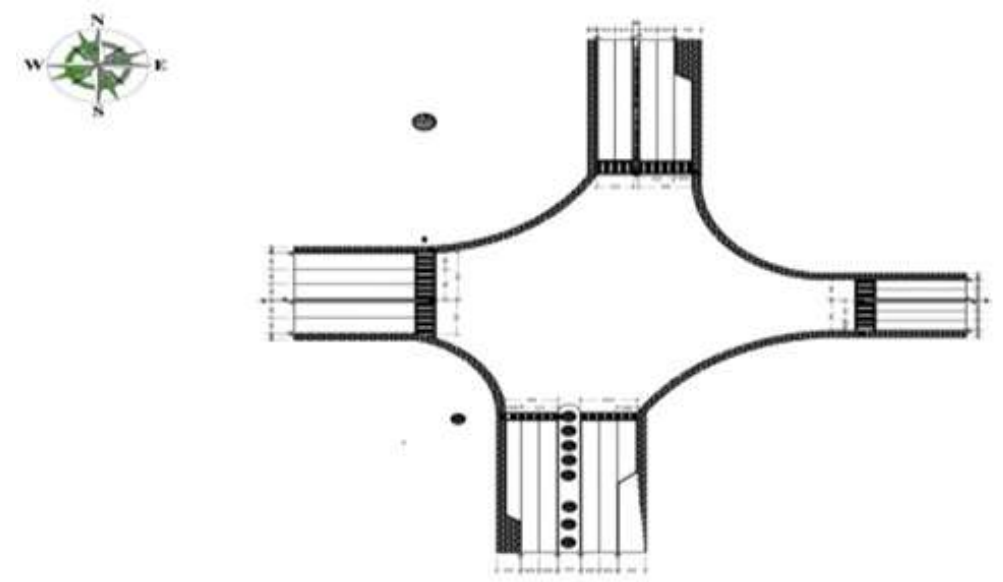

Gambar 3. Geometrik Simpang Jalan MT. Haryono - Ruhui Rahayu

Tabel 7. Rekapitulasi Form SIG II (Rasio Berbelok dan Volume Lalu lintas)

\begin{tabular}{|c|c|c|c|c|c|c|c|}
\hline \multirow{3}{*}{ Kode } & \multirow{3}{*}{ Arah } & \multicolumn{6}{|c|}{ Volume Kendaraan } \\
\hline & & \multirow{2}{*}{ LV (smp/jam } & \multirow{2}{*}{ HV (smp/jam } & \multirow{2}{*}{ MC (smp/jam } & \multirow{2}{*}{ Total Kendaraan } & \multicolumn{2}{|c|}{ Rasio Berbelok } \\
\hline & & & & & & PLT/LTOR & PRT \\
\hline \multirow{4}{*}{$\mathbf{U}$} & LT/LTOR & 95 & 3,9 & 38,4 & 137,3 & 0,15 & \\
\hline & ST & 351 & 2,6 & 134,6 & 488,2 & & \\
\hline & RT & 203 & 5,2 & 58 & 266,2 & & 0,30 \\
\hline & Total & 649 & 11,7 & 231 & 891,7 & & \\
\hline \multirow{4}{*}{$\mathbf{T}$} & LT/LTOR & 86 & 1,3 & 25,6 & 112,9 & 0,14 & \\
\hline & ST & 330 & 3,9 & 107 & 440,9 & & \\
\hline & RT & 209 & 2,6 & 66,2 & 277,8 & & 0,33 \\
\hline & Total & 625 & 7,8 & 198,8 & 831,6 & & \\
\hline \multirow{4}{*}{$\mathbf{S}$} & LT/LTOR & 107 & 0 & 25,2 & 132,2 & 0,15 & \\
\hline & ST & 356 & 3,9 & 125 & 484,9 & & \\
\hline & RT & 186 & 1,3 & 57,2 & 244,5 & & 0,28 \\
\hline & Total & 649 & 5,2 & 207,4 & 861,6 & & \\
\hline \multirow{4}{*}{ B } & LT/LTOR & 96 & 2,6 & 30,8 & 129,4 & 0,15 & \\
\hline & ST & 329 & 3,9 & 107,6 & 440,5 & & \\
\hline & RT & 208 & 2,6 & 77,4 & 288 & & 0,34 \\
\hline & Total & 633 & 9,1 & 215,8 & 857,9 & & \\
\hline
\end{tabular}

Sumber: Analisis Data

\subsection{Waktu Sinyal}

Waktu sinyal dianalisis berdasarkan Form SIG III, dalam form tersebut diuraikan hasil pengamatan fase, waktu all red, waktu kuning dan waktu hilang total yang terjadi berdasarkan kondisi di lapangan, sebagaimana dijabarkan berikut ini:

1) Penentuan fase sinyal

a. Fase 1 untuk pendekat Utara (Jl. Ruhui Rahayu).

b. Fase 2 untuk pendekat Timur (Jl. MT. Haryono).

c. Fase 3 untuk pendekat Selatan (Jl. Boulevard Raya) 
d. Fase 4 untuk pendekat Barat (Jl. MT. Haryono).

2) Berdasarkan hasil survei sinyal lampu lalu lintas, didapat waktu merah semua (all red) untuk masing-masing fase adalah 2 (dua) detik dan waktu kuning untuk masing-masing pendekat adalah 2 (dua) detik.

3) Waktu hilang total (LTI) diperoleh dengan hasil penjumlahan antara waktu merah semua (all red) dan waktu kuning, dengan kata lain waktu hilang total adalah penjumlahan waktu antar hijau (IG) pada setiap fase. Waktu hilang simpang MT. Haryono -Balikpapan baru adalah 16 detik.

\subsection{Kinerja Simpang}

Dari hasil analisis data diperoleh kinerja simpang berupa derajat kejenuhan, tundaan rata-rata dan tingkat pelayanan. Nilai DS untuk semua lengan pendekat berada di atas batas toleransi, dimana nilai DS dapat dinyatakan layaj jika DS $<0.7$. Rekapitulasi kinerja simpang dapat di lihat pada tabel 8 di bawah ini.

Tabel 8. Parameter Kinerja Simpang pada tiap lengan pendekat

\begin{tabular}{lcccc}
\hline \multirow{2}{*}{ Parameter } & \multicolumn{4}{c}{ Pendekat } \\
\cline { 2 - 5 } & Utara & Selatan & Barat & Timur \\
\hline Kapasitas simpang (C) smp/jam & 554.54 & 594.54 & 804.47 & 911.91 \\
Arus Lalu Lintas (Q) smp/jam & 754 & 719 & 729 & 728 \\
Derajat Kejenuhan (DS) & 1.36 & 1.21 & 0.91 & 0.80 \\
Jumlah kendaraan antri (NQ) smp/jam & 28 & 24 & 29 & 25 \\
Panjang antrian (QL) m & 85.01 & 80.89 & 73.3 & 103.1 \\
Tundaan rata-rata (D) detik/smp & 39.4 & 99.2 & 152.9 & 57.7 \\
Level of Service (LoS) & $\mathrm{D}$ & $\mathrm{F}$ & $\mathrm{F}$ & $\mathrm{E}$ \\
\hline
\end{tabular}

Sumber: Analisis data

\subsection{Evaluasi Kinerja Simpang dengan Program SIDRA Intersection}

\subsubsection{Degree of Saturation dan Level of Service Simpang}

Berdasarkan hasil running program SIDRA Intersection diperoleh hasil data movement performance yang terdiri atas hasil analisis Degree of Saturation (DS), Level of service (LoS), dan Average Speed.

Untuk nilai DS yang dihasilkan terdiri atas nilai DS setiap lajur per lengan simpang, dimana untuk lengan simpang selatan (Balikpapan Baru) nilai DS simpang sebesar 1,2, sedangkan nilai DS per lajur/arah untuk lajur belok kiri langsung sebesar 0,048, DS arah belok kanan sebesar 1,2 dan DS arah lurus sebesar 1,2. Data selengkapnya dapat dilihat pada tabel 6 dan nilai LoS pada lajur untuk masing-masing lengan pendekat dapat di lihat pada Gambar 4.

Tabel 6. DS Pada Setiap Lengan Simpang

\begin{tabular}{lllllll}
\hline & & South & East & North & West & Intersection \\
\hline $\begin{array}{l}\text { Degree } \\
\text { Saturation }\end{array}$ & of & 1.22 & 1.22 & 1.23 & 1.21 & 1.23 \\
\hline
\end{tabular}

Sumber: Analisis Data 


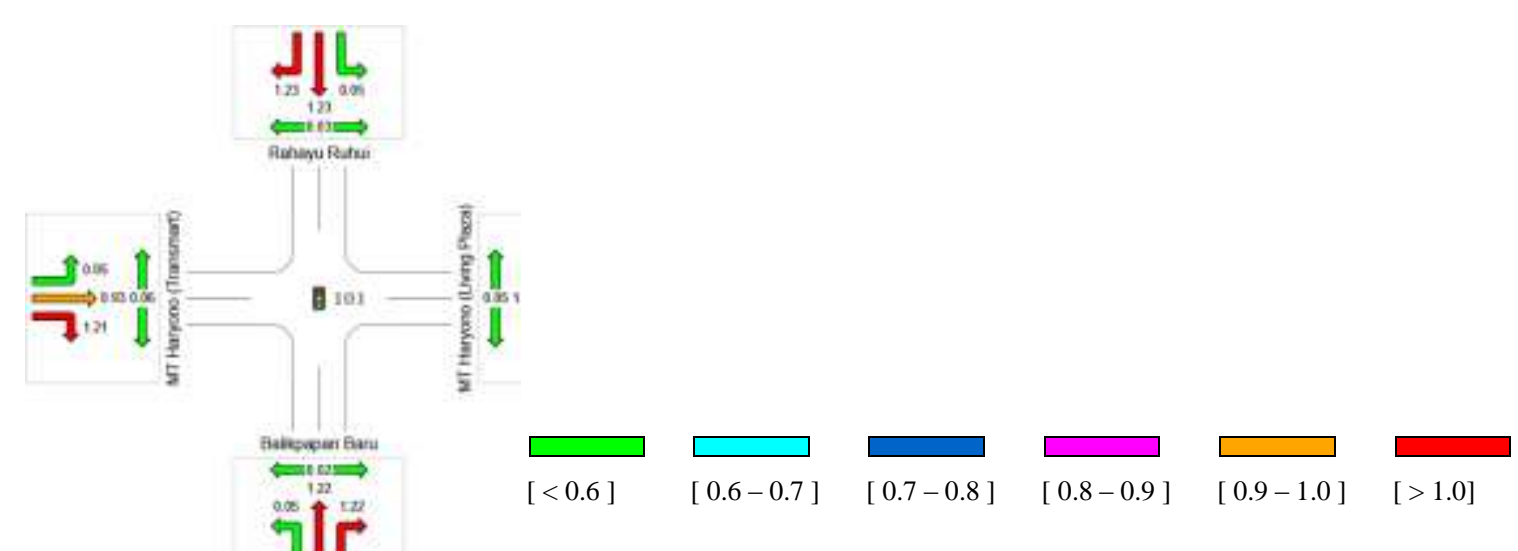

Gambar 4. Skema DS setiap lajur per lengan simpang

Berdasarkan hasil analisis, tingkat pelayanan (Level of Service) simpang berada pada tingkat pelayanan $\mathrm{F}$ (Tabel 7) yang berarti memiliki tingkat pelayanan terburuk, dimana tundaan kendaraan pada setiap lengan simpang (delay) $>80$ detik/kend (HCM, 2000). Pada Sidra nilai tundaan menggunakan satuan kend/jam yang merujuk pada HCM 2000 berbeda dengan MKJI yang menggunakan satuan smp/jam, dimana setiap kendaraan sudah dikonversi menggunakan koefisien emp masing-masing kendaraan. Berdasarkan gambar 5 dapat diketahui bahwa pada analisis menggunakan Sidra, waktu tundaan yang dihasilkan berdasarkan per lajur pada setiap lengan simpang/pendekat, dimana waktu tunda (delay) pada setiap lengan simpang berada dikisaran angka 170 detik/kendaraan untuk lajur belok kanan, 120 detik/kendaraan untuk lajur lurus dan 2.6 detik/kendaraan untuk lajur belok kiri langsung. Nilai LoS untuk lengan pendekat yang lain selengkapnya dapat dilihat pada Tabel 7 dan Gambar 5 di bawah ini.

Tabel 7. Tingkat Pelayanan (Level of Service)

\begin{tabular}{llllll}
\hline & South & East & North & West & Intersection \\
\hline LOS & F & F & F & F & F \\
\hline
\end{tabular}

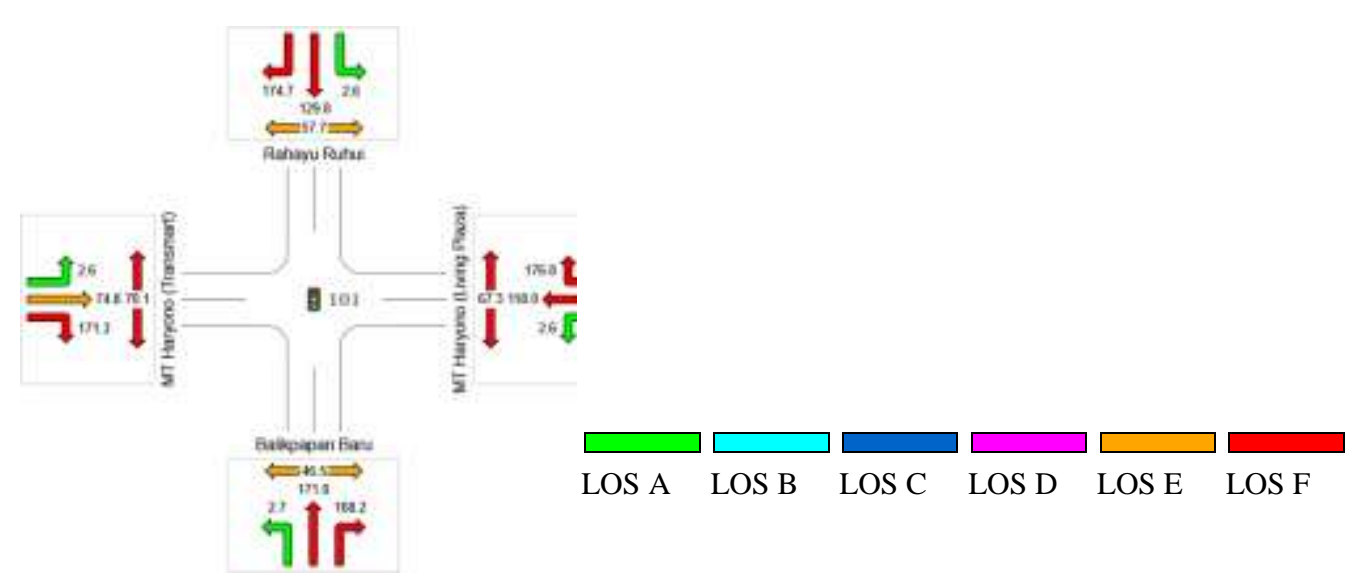

Gambar 5. Tingkat Pelayanan (LOS) dan Waktu tunda (delay) Pada Simpang Jalan MT. HaryonoJalan Ruhui Rahayu Sumber: Analisis Data

\subsubsection{Phasing Summary}

Berdasarkan data input real di lapangan berupa lama waktu kuning, all red, siklus time dan cycle time, maka diperoleh output pembagian waktu per fase dengan total green time per fase berbeda 
dengan data real lapangan. Misal pada green time lapangan untuk pendekat utara (Ruhui Rahayu) sebesar 27 detik sedangkan pada analysis sidra sebesar 40 detik sehingga terdapat selisih green time sebesar 13 detik pada pendekat utara, hal ini disebabkan adanya perbedaan parameter dan rujukan yang digunakan dimana analisis sidra berdasarkan highway Capacity Manual 2000. Untuk data selengkapnya dapat di lihat pada tabel 8 dan gambar 6 berikut.

Tabel 8. Phase Timing

\begin{tabular}{lllll} 
Phase & A & B & C & D \\
\hline Phase Change Time (sec) & 0 & 31 & 75 & 103 \\
Green Time (sec) & 27 & 40 & 24 & 56 \\
Phase Time (sec) & 31 & 44 & 28 & 60 \\
Phase Split & $19 \%$ & $27 \%$ & $17 \%$ & $37 \%$
\end{tabular}

Sumber: Analisis data

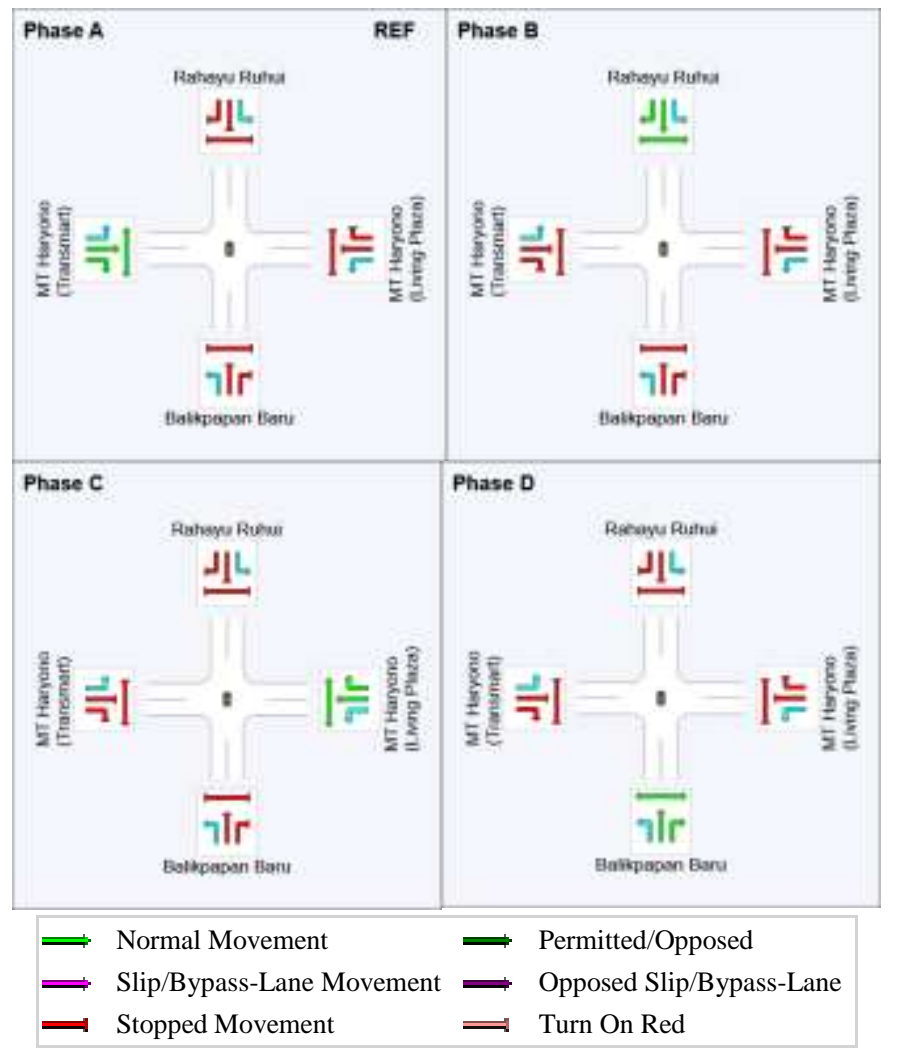

Gambar 6. Skema Fase pada setiap lengan simpang (sumber: Analisis Data)

\subsection{Perbedaan Kinerja MKJI dan SIDRA Intersection}

Dari hasil evaluasi kinerja simpang terdapat perbedaan hasil yang signifikan antara metode MKJI dan Sidra, terutama pada jumlah kendaraan antri (NQ) dan panjang antrian (QL) sebagaimana terlihat dalam tabel 9. Beberapa hal yang dapat menyebabkan perbedaan hasil analisis antara lain:

a. Perbedaan metodologi antara perhitungan MKJI dengan SIDRA yang biasanya mengacu pada HCM.

b. Pada SIDRA analisis menggunakan pendekatan GAP acceptance dan bunching, yang berarti melibatkan perilaku berkendara dalam analisis kinerja persimpangan.

c. Pada SIDRA faktor crossing pedestrian juga dipertimbangkan sedangkan pada MKJI tidak. 
Tabel 9. Perbedaan Kinerja Simpang metode MKJI 1997 dan SIDRA Intersection

\begin{tabular}{|c|c|c|c|c|c|c|c|c|}
\hline \multirow{3}{*}{ Parameter } & \multirow{2}{*}{\multicolumn{4}{|c|}{$\begin{array}{c}\text { MKJI } \\
\text { Pendekat }\end{array}$}} & \multirow{2}{*}{\multicolumn{4}{|c|}{$\begin{array}{c}\text { SIDRA } \\
\text { Pendekat }\end{array}$}} \\
\hline & & & & & & & & \\
\hline & Utara & Selatan & Barat & Timur & Utara & Selatan & Barat & Timur \\
\hline Phase & A & $\mathrm{C}$ & $\mathrm{D}$ & $\mathrm{B}$ & B & $\mathrm{D}$ & $\mathrm{C}$ & A \\
\hline Green time & 27 & 38 & 37 & 38 & 40 & 56 & 24 & 27 \\
\hline $\begin{array}{l}\text { Phase time } \\
\text { (yellow+all red) }\end{array}$ & 31 & 42 & 41 & 42 & 44 & 60 & 28 & 31 \\
\hline $\begin{array}{l}\text { Kapasitas simpang } \\
\text { (C) smp/jam }\end{array}$ & 554.54 & 594.54 & 804.47 & 911.91 & 554.54 & 594.54 & 804.47 & 911.91 \\
\hline $\begin{array}{l}\text { Arus Lalu Lintas (Q) } \\
\text { smp/jam }\end{array}$ & 754 & 719 & 729 & 728 & 754 & 719 & 729 & 728 \\
\hline $\begin{array}{l}\text { Derajat Kejenuhan } \\
\text { (DS) }\end{array}$ & 1.36 & 1.21 & 0.91 & 0.80 & 1.22 & 1.22 & 1.21 & 1.23 \\
\hline $\begin{array}{ll}\text { Jumlah } & \text { kendaraan } \\
\text { antri (NQ) } & \end{array}$ & $\begin{array}{l}28 \\
\text { smp }\end{array}$ & $\begin{array}{l}24 \\
\text { smp }\end{array}$ & $\begin{array}{l}29 \\
\text { smp }\end{array}$ & $\begin{array}{l}25 \\
\text { smp }\end{array}$ & 93 kend & 132 kend & $\begin{array}{l}77.9 \\
\text { kend }\end{array}$ & $\begin{array}{l}93 \\
\text { kend }\end{array}$ \\
\hline $\begin{array}{l}\text { Panjang antrian (QL) } \\
\mathrm{m}\end{array}$ & 85.01 & 80.89 & 73.3 & 103.1 & 310 & 278 & 332 & 310 \\
\hline $\begin{array}{l}\text { Tundaan rata-rata (D) } \\
\text { detik/smp }\end{array}$ & 39.4 & 99.2 & 152.9 & 57.7 & 97 & 147 & 97 & 122.3 \\
\hline $\begin{array}{l}\text { Level of } \quad \text { Service } \\
(\mathrm{LoS})\end{array}$ & $\mathrm{D}$ & $\mathrm{F}$ & $\mathrm{F}$ & $\mathrm{E}$ & $\mathrm{F}$ & $\mathrm{F}$ & $\mathrm{F}$ & $\mathrm{F}$ \\
\hline
\end{tabular}

\section{Kesimpulan}

Berdasarkan hasil evaluasi kinerja simpang dengan metode MKJI diperoleh nilai LoS D pada lengan pendekat utara dengan nilai tundaan sebesar $39.4 \mathrm{det} / \mathrm{smp}$, nilai LoS F pada lengan pendekat selatan dan barat dengan nilai tundaan masing $99.2 \mathrm{det} / \mathrm{smp}$ dan $152.9 \mathrm{det} / \mathrm{smp}$, dan untuk pendekat timur nilai Los E dengan waktu tundaaan sebesar 57.7 det/smp. Sedangkan pada analisis Sidra Intersection diperoleh nilai LoS F pada semua lengan pendekat dengan waktu tundaan rata-rata pada semua simpang sebesar $122 \mathrm{det} / \mathrm{kend}$. Hal ini dapat diartikan bahwa rata-rata setiap kendaraan membutuhkan waktu tambahan sebesar 122 detik untuk dapat keluar dari titik simpang, waktu tundaan ini jauh lebih besar dari waktu tundaan yang diijinkan yakni tidak lebih dari 50 detik/kendaraan. Untuk nilai DS pada metode MKJI dan Sidra Intersection terdapat perbedaan, dimana nilai DS MKJI pada lengan pendekat utara sebesar 1.36, pendekat selatan 1.21, pendekat barat 0.91, dan pendekat timur 0.80 sedangkan nilai DS berdasarkan Sidra Intersectioan adalah sebesar 1.2. Beberapa hal yang menyebabkan perbedaan hasil analisis antara MKJI dan SIDRA antara lain, adanya perbedaan metodologi antara perhitungan MKJI dengan SIDRA yang biasanya mengacu pada HCM, pada SIDRA analisis menggunakan pendekatan GAP acceptance dan bunching yang berarti melibatkan perilaku berkendara dalam analisis kinerja persimpangan serta faktor crossing pedestrian juga dipertimbangkan pada SIDRA sedangkan pada metode MKJI tidak diperhitungkan. Dari hasil evaluasi kinerja simpang diketahui bahwa simpang empat Jalan MT. Haryono - Jalan Ruhui Rahayu memiliki kinerja yang yang buruk sehingga sudah perlu penanganan sebagai upaya perbaikan kinerja simpang. Beberapa upaya dapat dilakukan sebagai alternatif penanganan simpang salah satunya redesain geometrik simpang dapat dilakukan dengan penambahan lebar lajur maupun penambahan lajur khusus belok kiri maupun belok kanan yang nantinya akan mempengaruhi saturated flow hingga waktu siklus. Diharapkan dengan adanya langkah nyata penanganan simoang dapat memberika tingkat pelayanan yang lebih baik kepada pengendara sebagai pengguna jalan. 


\section{Daftar Pustaka}

Anonim. 1997. Manual Kapasitas Jalan Indonesia (MKJI) 1997. Direktorat Jenderal Bina Marga Departemen Pekerjaan Umum RI. Jakarta.

Arnetha Sari Raintung. 2012. Perbandingan Pengukuran Kinerja Simpang Bersinyal Menggunakan Program Aasidra 2.0 Dan MKJI 1997. Jurnal Ilmiah Media Engineering Vol. 2, No. 1.

Badan Pusat statistik. 2019. Kota Balikpapan Dalam Angka 2019. BPS Kota Balikpapan

Dwijoko Ansusanto, Siprianus Tanggu. 2016. Analisis Kinerja Dan Manajemen Pada Simpang Dengan Derajat Kejenuhan Tinggi. Jurnal Dinamika Rekayasa.

Iqbal, Sugiharto, dan M. Isya. 2017. Kinerja dan Tingkat Pelayanan Simpang Bersinyal pada Simpang Remi Kota Langsa. Jurnal teknik Sipil Universitas Syiah Kuala, Vol. 1 No. 1.

Julia Astuti Djumiati, M.J. Paransa, F.M. Jansen. 2013. Evaluasi Kinerja Simpang Bersinyal Menggunakan Program aaSIDRA. Jurnal Sipil Statik Vol.1 No. 5.

John H. Frans, Tri M.W, dan Charly L. Oematan. 2018. Perencanaan dan Kinerja Bundaran Berdasarkan Metode MKJI 1997 dan Sidra Intersection V5.1, Jurnal Teknik Sipil, Vol. VII, No. 2.

M.Zainul Arifin, Ari widya Permana, Hendi Bowo Putro. 2017. Studi Koordinasi Simpang Bersinyal. Prosiding Simposium Forum Studi Transportasi antar Perguruan Tinggi ke-20 Universitas Hasanuddin. Makassar.

Ofyar Z Tamin. 2008.Perencanaan, Pemodelan, dan Rekayasa Transportasi. Penerbit ITB Bandung.

Rama Dwi Aryandi, Ari Sandhyavitri, dan Reni Suryanita. 2017. Peningkatan Kinerja Simpang Melalui Manajemen Hambatan Samping dan Pengaturan Arus Lalu Lintas. Jurnal Sains dan Teknologi 16 (2) 38-47. 